\title{
PREDICTION OF BENDING PROPERTIES FOR BEECH LUMBER USING STRESS WAVE METHOD
}

\author{
Ergun Guntekin ${ }^{1, \star}$, Serhat Ozkan ${ }^{1}$, Tugba Yilmaz ${ }^{1}$
}

\begin{abstract}
In this study; bending properties of beech wood (Fagus orientalis) were predicted using stress wave method and compared with static bending tests. First, lumbers which were different in length and cross section were weighed and dimensions were measured. Then, moisture contents were obtained via moisture meter. By using the density, moisture, and dimensions of the samples in MTG Timber Grader device, dynamic modulus of elasticity values were determined. And then, samples were subjected to 3 point bending test. Modulus of elasticity and bending strengths were calculated using load - deformation curves. Regression models were developed to interpret relationships between dynamic modulus elasticity and bending properties. Results showed that there is a high regression coefficient $(0,86)$ between dynamic modulus of elasticity and static modulus of elasticity. Regression coefficient between dynamic modulus of elasticity and static bending strength was measured as $(0,72)$ and regression coefficient between static modulus of elasticity and static bending strength was measured as $(0,74)$. Results indicate that bending properties of beech wood lumber can be predicted using stress wave method.
\end{abstract}

Keywords: Fagus orientalis, bending properties, stress wave.

\section{INTRODUCTION}

Most strength properties and modulus of elasticity (MOE) of wood have a positive linear relationship, so that strength properties of wood may be estimated by MOE. MOE of wood can be determined by static or nondestructive evaluation (Yang et al. 2008).

Nondestructive evaluation (NDE) of wood has drawn attention, especially with regard to mechanical grading. A large number of investigations exists dealing with the determination of the MOE and its correlation with modulus of rupture in bending. Static and dynamic MOE determinations were compared by number of papers which good correlations have been reported between the two MOE values (Ross and Pellerin 1994, Divós and Tanaka 2005). Vibration, stress wave and ultrasonic wave velocity are particularly important in obtaining the MOE. Ultrasonic wave velocity has more advantages over other techniques in practical terms (Esteban et al. 2009). Stress-wave-based NDE methods have been investigated extensively during the past few decades and have shown promise for predicting the mechanical properties of wood based materials. Stress wave base methods have been applied and good correlations have been achieved in the case of detecting defects on standing trees (Wang et al. 2004), determining bending properties of small diameter logs (Wang et al. 2001), wood-derived products such as laminated veneer lumber (Ross et al. 1998), glued-laminated wood (Yang et al. 2008), reconstituted wood products (Han et al. 2005), diagnosing components of timber structures (Clausen et al. 2001).

\footnotetext{
Department of Forest Products Engineering. Faculty of Forestry. Suleyman Demirel University, 32260 Isparta, Turkey

Received: 19.12. 2012 Accepted: 29.04. 2013

^Corresponding Author: ergunguntekin@sdu.edu.tr
} 
The beech (Fagus orientalis) is one of the most important commercial hardwood species in Turkish forestry, and covers a total of 1335786 ha, about 6.43\% of Turkey's forests (Bektas et al. 2002). Its wood has been used in variety of applications including construction and furniture making. The purpose of this study was to predict bending properties of beech wood lumber using stress wave method.

\section{MATERIALS AND METHODS}

Total of 106 pieces of beech (Fagus orientalis Lipsky) lumbers which were approximately $50 \mathrm{x}$ $70 \mathrm{~mm}$ in cross section and 2 meter in length were supplied from a commercial manufacturer. All the lumbers were Grade 1 according to TS EN 975-1 (2000). After the lumber had been delivered to the laboratory, they were conditioned at $65 \%$ relative humidity and $23{ }^{\circ} \mathrm{C}$, moisture content (MC) was measured using dielectric type moisture meter, dimensions were measured and weighed. Apparent density was calculated. After the measurements, dynamic MOE values of the lumber were determined by employing Timber Grader MTG, which works on a principle of stress wave (Rozema 2007). Following dynamic measurement, static bending properties were measured using center point bending test in accordance with ASTM D 198 (ASTM 2002) as shown in figure 1. Samples depth to span (h/L) ratios varied between 0.0308 and 0.058 . Apparent $\mathrm{MOE}$ and bending strength of the samples were evaluated from load-deformation curves obtained. The following equations were utilized to calculate MOE and bending strength:

Where:

$$
\begin{gathered}
\text { Bending Strength }=\frac{3 P L}{2 b h^{2}} \\
M O E=\frac{\Delta F L^{3}}{\Delta d 4 b h^{3}}
\end{gathered}
$$

$P=$ maximum load $(\mathrm{N})$,

$L=\operatorname{span}(\mathrm{mm})$,

$h=$ specimen height $(\mathrm{mm})$,

$b=$ specimen width (mm),

$\Delta F=$ load at elastic region $(\mathrm{N})$,

$\Delta d=$ corresponding deformation at elastic region $(\mathrm{mm})$.

Statistical analysis was performed in order to interpret relationship between dynamic MOE and bending properties.

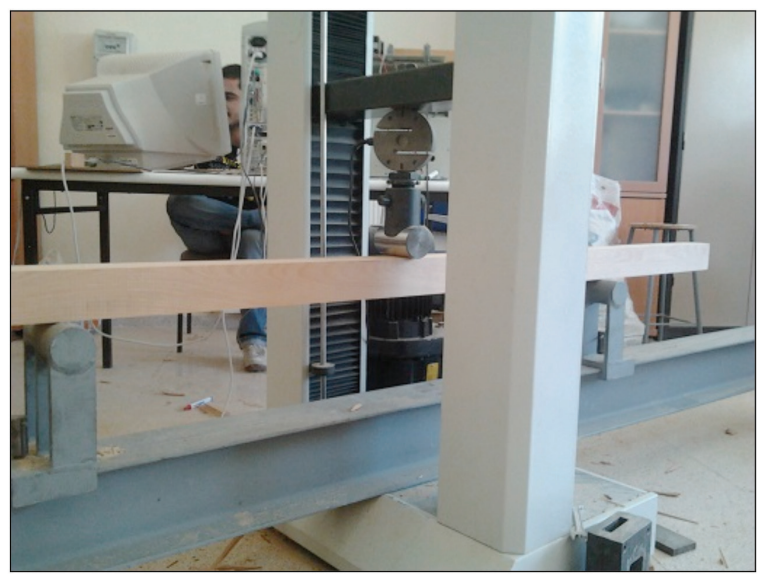

Figure 1. Static testing of beech lumbers using center point bending test. 


\section{RESULTS AND DISCUSSION}

Some physical and mechanical parameters of the lumbers measured are presented in table 1 . The results indicated that the values of the dynamic MOE were significantly higher than static MOE in bending of the lumber because they include no shear. The relationship between static and dynamic MOE is shown in figure 2. The relationship between bending strength and dynamic MOE is shown in figure 3. The relationship between static MOE and bending strength is presented in figure 4 .

Table 1. Average measured values of the lumbers tested.

\begin{tabular}{|c|c|c|c|c|}
\hline Property & Mean & Max. & Min. & $\begin{array}{c}\text { Coefficient of } \\
\text { Variation }\end{array}$ \\
\hline Moisture (\%) & 9,05 & 14,8 & 5,8 & 11.27 \\
\hline Density $\left(\mathrm{kg} / \mathrm{m}^{3}\right)$ & 590 & 710 & 460 & 8,47 \\
\hline Frequency $(\mathrm{Hz})$ & 1270 & 1513 & 849 & 10.78 \\
\hline Dynamic MOE (MPa) & 10764 & 15341 & 5763 & 20,48 \\
\hline Static MOE (MPa) & 10110 & 14704 & 5554 & 19,03 \\
\hline Bending Strength (MPa) & 90,54 & 127,14 & 47.64 & 18,32 \\
\hline
\end{tabular}

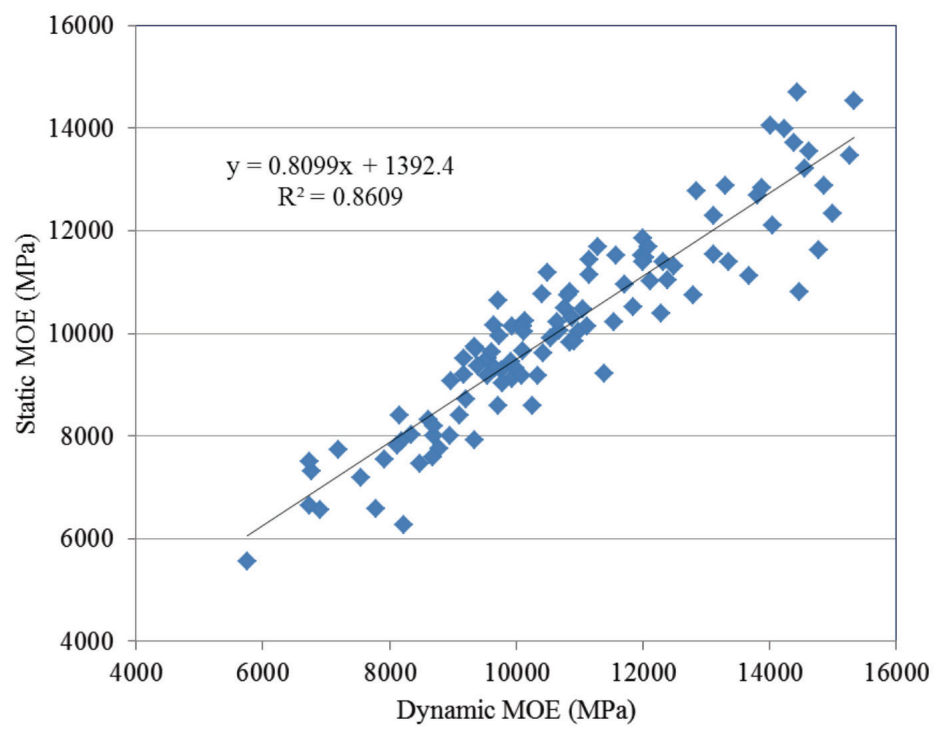

Figure 2. Relationship between static and dynamic MOE of beech lumbers. 


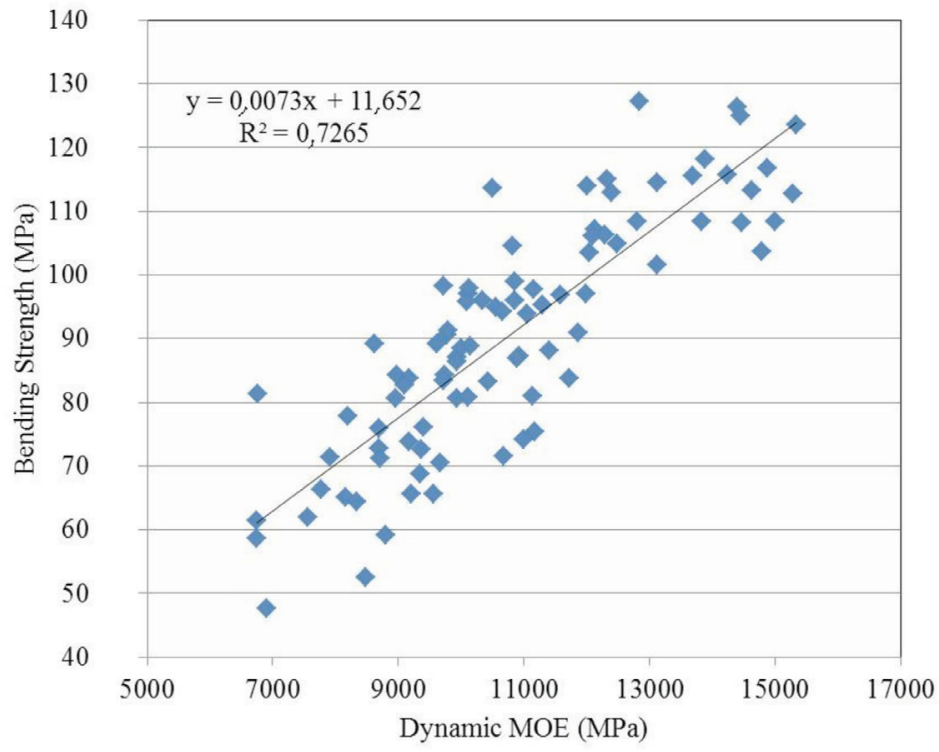

Figure 3. Relationship between bending strength and dynamic MOE of beech lumbers.

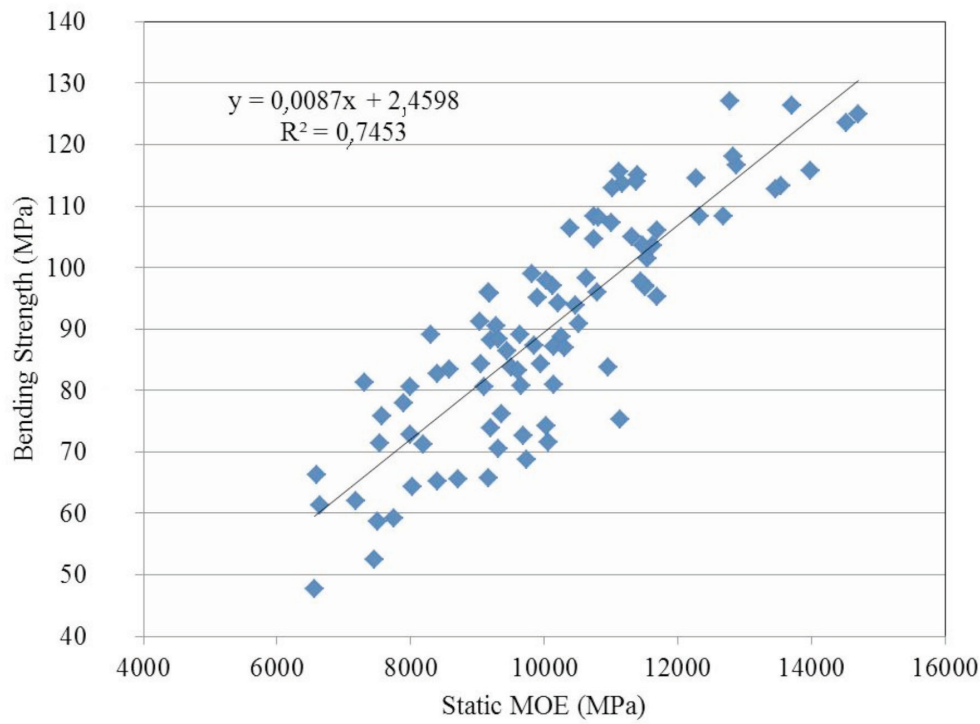

Figure 4. Relationship between bending strength and static MOE of beech lumbers.

Density values of the beech lumbers ranged from 460 to $719 \mathrm{~kg} / \mathrm{m}^{3}$ with an average of 590 . This value is on lower side of the average density values $\left(589-669 \mathrm{~kg} / \mathrm{m}^{3}\right)$ for clear beech samples at $12 \%$ MC reported by Bektas et al. (2002).

Bending strength of the clear beech wood samples at $12 \% \mathrm{MC}$ ranged between 87 and $123 \mathrm{MPa}$ in the literature depending upon density, age and the location of growth (Guler and Bektas 2000). Bending strength of the beech wood used in the study is $90,54 \mathrm{MPa}$. Average MOE of the samples tested in this study is $10110 \mathrm{MPa}$, and it is close to the average MOE values (6600 to $16000 \mathrm{MPa}$ ) reported by Guler and Bektas (2000) for beech wood in the literature. 
Several studies have reported that values of dynamic MOE are higher than those obtained using static bending tests (Teles et al. 2011, Passialis and Adamopoulos 2002, Barrett et al. 2008). The lower static MOE values were expected because static measurement includes shear deflection whereas MTG results are shear free MOE values (Barrett et al. 2008). In non-destructive evaluation of wood, $\mathrm{r}^{2}$ values are usually depend on the methods, species used, moisture content, type of samples tested, and etc. Results of nondestructive testing on wood were summarized by Ross and Pellerin (1994). They have stated that $\mathrm{r}^{2}$ values can be as high as 0,98 and 0,88 for clear wood species and dimension lumber, respectively. Divos and Tanaka (2005) reported that $\mathrm{r}^{2}$ values between static and dynamic MOE values can be between 0,9 and 0,96 , and dynamic MOE values are usually $10 \%$ higher than the static MOE values. Biechele et al. (2010) have reached $\mathrm{r}^{2}$ values of 0,80 and 0,97 for spruce timber using stress wave and transverse vibration methods, respectively while Teles et al. (2011) have reported $\mathrm{r}^{2}$ values of 0,84 and 0,94 for tropical hardwood species using same methods. Ravenshorst and Kuilen (2006) evaluated bending properties of thirty different hardwood species using both destructive and non-destructive testing. They have reached a coefficient of determination of 0,62 and 0,85 for bending strength and bending elasticity, respectively. Krzosek et al. (2008) tested Polish grown structural pine lumber employing several nondestructive methods including MTG. They have reported a coefficient of determination of 0,84 for bending stiffness. Similar coefficient of determination value has been reported by Guntekin et al. (2013) for bending stiffness of Turkish Red pine.

\section{CONCLUSIONS}

First grade beech lumbers were tested in order to evaluate bending properties using both nondestructive and destructive methods. Samples had an average density of $0,59 \mathrm{~kg} / \mathrm{m}^{3}$ and an average MC of 9,05 $\%$. The coefficient of determination between dynamic and static MOE is 0,8609. Coefficient of determination between dynamic MOE and static bending strength was measured as 0,7265 and coefficient of determination between static MOE and static bending strength was measured as 0,7453 . Coefficient of determination between dynamic MOE and bending strength is very close to coefficient of determination between static MOE and bending strength. It can be concluded that bending properties of beech wood can be estimated using stress wave method.

\section{REFERENCES}

ASTM. American Society for Testing and Materials. 2002. Standard Test Methods of Static Tests of Lumber in Structural Sizes. D198-99: 59-78 in Annual Book of ASTM Standards. Philadelphia.

Barrett, J.D.; Lam, F.; Chen, Y. 2008. Comparison of machine grading methods for Canadian Hemlock. In: Proceedings of 10th WCTE Miyazaki. Japan. 6 p.

Bektas, İ.; Guler, C.; Baştürk, M.A. 2002. Principal mechanical properties of Eastern Beech Wood (Fagus orientalis Lipsky) naturally grown in Andırın-Northeastern Mediterranean region of Turkey. Turk J Agric For 26(3): 147-154.

Biechele, T.; Chui, Y.H.; Gong, M. 2010. Assessing stiffness on finger-jointed timber with different non-destructive testing techniques. In: The Future of Quality Control for Wood \& Wood Products, Final Conference of COST Action E53. 4-7th May 2010, Edinburgh, UK. 7 p.

Clausen, C.A.; Ross, R.J.; Forsman, J.W.; Balachowski, J.D. 2001. Condition assessment of roof trusses of Quincy mine blacksmith shop in Keweenaw National Historical Park. U.S. Department of Agriculture. Forest Products Laboratory. Research Note: 0281, Madison. 7 p.

Divós, F.; Tanaka, T. 2005. Relation between static and dynamic modulus of elasticity of wood. Acta Silv Lign Hung 1:105-110. 
Esteban, L.G.; Fernandez, F.G.; de Palacios, P. 2009. MOE prediction in Abies pinsapo Boiss. timber: Application of an artificial neural network using non-destructive testing. Comput Struct 87: 1360-1365.

Guler, C.; Bektas, İ. 2000. Andırın Doğu Kayını (Fagus orientalis L.) odunuda elastiklik özellikler ile yoğunluk arasındaki ilişki. KSÜ Fen ve Mühendislik Dergisi 3(2):51-57.

Guntekin, E.; Emiroglu, Z.G.; Yılmaz, T. 2013. Prediction of bending properties for Turkish Red Pine Lumber using Stress Wave Method. BioResources 8(1): 231-237.

Han, G.; Wu, Q.; Wang, X. 2005. Stress-wave velocity of wood-based panels: Effect of moisture, product type, and material direction. Forest Prod J 56 (1):28-33.

Krzosek, S.; Grzeskiewicz, M.; Bacher, M. 2008. Mechanical properties of Polish - grown Pinus silvestris L. Structural sawn timber. Conference COST E53, 29-30 October 2008, Delft, The Netherlands, pp $253-260$.

Passialis, C.; Adamopoulos, S. 2002. A comparison of three NDT methods for determining the modulus of elasticity in flexure of fir and black locust small clear wood specimens. Holz Roh Werkst 60: $323-324$.

Ravenshorst, G.J.P.; Van De Kuilen, J.W.G. 2006. An innovative species independent strength grading model. In: 9th World Conference in Timber Engineering. August 6-10, 2006. 8 p.

Ross, R.J.; Pellerin, R.F. 1994. Nondestructive testing for assessing wood members in structures: A review. U.S. Department of Agriculture. Forest Products Laboratory. Technical Report: 70, Madison. 42 p.

Ross, R.J.; Bradshaw, B.K.; Pellerin, R.F. 1998. Nondestructive evaluation of wood. Forest Prod $J$ 48(1):14-19.

Rozema, P. 2007. Timber Grader MTG - Brookhuis Micro-Eletronics BV the Netherlands. In: The Future of Quality Control for Wood \& Wood Products. Conference of COST Action E53. 17 $7^{\text {th }}$ October 2007, Warsaw, Poland. 7 p.

Teles, R.F., Del Menezzi, C.S., De Souza, F., De Souza, M.R., 2011. Nondestructive evaluation of a tropical hardwood: Interrelationship between methods and physical-acoustical variables. Ci Madeira 2(1): 01-14.

TS EN 975-1. 2000. Sawn timber- Appearance grading of hardwoods- Part 1: Oak and beech. Turkish Standard Institute, Ankara. 37 p.

Wang, X.; Ross, R.J.; Mattson, J.A.; Erickson, J.R.; Forsman, J.W.; Geske, E.A.; Wehr, M.A. 2001. Several nondestructive evaluation techniques for assessing stiffness and MOE of small- diameter logs. U.S. Department of Agriculture. Forest Products Laboratory, Research Paper: 600, Madison. 15 p.

Wang, X.; Divos, F.; Pilon, C.; Brashaw, B.K.; Ross, R.J.; Pellerin, R.F. 2004. Assessment of decay in standing timber using stress wave timing nondestructive evaluation tools. U.S. Department of Agriculture. Forest Products Laboratory, Technical Report: 147. Madison. 14 p.

Yang, T.H.; Wang, S.Y.; Lin, C.J.; Tsai, M.J. 2008. Evaluation of the mechanical properties of Douglas-fir and Japanese Cedar lumber and its structural glulam by non-destructive techniques. Constr Build Mater 22: 487-493. 